
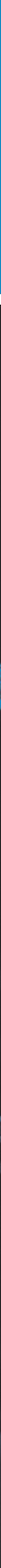
Editorial Group

MARTIN CLOONAN (Book Review Editor)

NANETTE DE JONG

DAI GRIFFITHS

SARAH HILL (Co-ordinating Editor)

\section{Founding Editors}

\section{DAVID HORN}

RICHARD MIDDLETON

\section{International Advisory Editors}

Christopher Ballantine (South Africa)

Alf Björnberg (Sweden)

Barbara Bradby (Ireland)

Sara Cohen (UK)

Anne Danielsen (Norway)

Nicola Dibben (UK)

Franco Fabbri (Italy)

Murray Forman (USA)

Héctor Fouce (Spain)

Simon Frith (UK)

Juan Pablo González (Chile)

Lucy Green (UK)

Line Grenier (Canada)

Jill Halstead (Norway)

(c) Cambridge University Press 2016
BARBARA LEBRUN

ALLAN MOORE (Co-ordinating Editor)

KEITH NEGUS

JOHN STREET

Popular Music is an international multi-disciplinary journal covering all aspects of the subject - from the formation of social group identities through popular music, to the workings of the global music industry, to how particular pieces of music are put together. The journal includes all kinds of popular music, whether rap or rai, jazz or rock, from any historical era and any geographical location. Popular Music carries articles by scholars from a variety of disciplines and theoretical perspectives. Each issue contains substantial, authoritative and influential articles, topical pieces, and reviews of a wide range of books. Some issues are thematic. The editors also welcome polemical pieces for the 'Middle Eight' section of the journal. Contributors should consult the 'Notes' on the inside back cover.

Articles and any other material not related to reviews should be submitted online at http://journals. cambridge.org/pmu. Any queries relating to submissions may be addressed to popularmusic@cambridge.org. Material for review should be sent to Professor Martin Cloonan, email martin.cloonan@music.glasgow.ac.uk.

Subscriptions Popular Music (ISSN 0261-1430) is published three times a year in January, May and October. Three parts form a volume. The subscription price (excluding VAT) of Volume 35 which includes print and electronic access to institutional subscribers is $£ 263$ (USA, Canada and Mexico \$450); print only for individuals is $£ 56$ (USA, Canada and Mexico \$84). Single parts cost $£ 98$ (USA, Canada and Mexico \$161). An online only price is available to institutional subscribers for $£ 226$ (USA, Canada and Mexico \$379). EU subscribers (outside the UK) who are not registered for VAT should add VAT at their country's rate. VAT registered subscribers should provide their VAT registration number. Orders, which must be accompanied by payment, may be sent to a bookseller, subscription agent or direct to the publisher: Cambridge University Press, Journals Fulfillment Department, UPH, Shaftesbury Road, Cambridge CB2 8BS, UK. Orders from the USA, Canada and Mexico should be sent to Cambridge University Press, Journals Fulfillment Department, 100 Brook Hill Drive, West Nyack, New York 10994-2133. Japanese prices for institutions are available from Kinokuniya Company Ltd, P.O. Box 55, Chitose, Tokyo 156, Japan. Prices include delivery by air.

Claims for missing issues should be made immediately on receipt of the subsequent issue.

Copying This journal is registered with the Copyright Clearance Center, 222 Rosewood Drive, Danvers, MA 01923. Organizations in the USA who are also registered with the C.C.C. may therefore copy material (beyond the limits permitted by sections 107 and 108 of US copyright law) subject to payment to C.C.C. of the per copy fee of $\$ 12.00$. This consent does not extend to multiple copying for promotional or commercial purposes. Code 0261$1430 / 2013 \$ 12.00$. Organizations authorized by the Copyright Licensing Agency may also copy material subject to the usual conditions.

ISI Tear Sheet Service, 3501 Market Street, Philadelphia, Pennsylvania 19104, USA, is authorized to supply single copies of separate articles for private use only.

For all other use, permission should be sought from the Cambridge or New York offices of Cambridge University Press.

INTERNET ACCESS This journal is included in the Cambridge Journals Online service at http://journals.cambridge.org. For further information on Popular Music and all other Cambridge journals see http://www.cambridge.org. 
VOL. 35 NO. 1

January

Issue Editors:

Martin Cloonan

Nanette de Jong

\section{Popular Music}

\section{Contents}

iii The Contributors

AMY KINTNER $\mathbf{1}$ Back to the garden again: Joni Mitchell's 'Woodstock' and utopianism in song

PATRYK GALUSZKA AND KATARZYNA M. WYRZYKOWSKA

IAN CAWOOD

23 Running a record label when records don't sell anymore: empirical evidence from Poland

41 'Don't let me go! Hold me down!': inspiration, voice and image in Kate Bush's 'Hounds of Love'

AKSEL TJORA 64 The social rhythm of the rock music festival

CHARLES MUELLER 84 Baudrillard's Blues

ADAM TRAINER $\mathbf{1 0 0}$ Perth punk and the construction of urbanity in a suburban city

\section{Obituary}

DEREK B. SCOTT AND STAN HAWKINS

118 Remembering Sheila Whiteley

\section{Reviews}

BRUCE JOHNSON

122 Black British Jazz: Routes, Ownership and Performance, edited by Jason Toynbee, Catherine Tackley and Mark Doffman

SARAH HANKINS

124 The Arab Avant-Garde: Music, Politics, Modernity, edited by Thomas Burkhalter, Kay Dickinson and Benjamin J. Harbert

ALEXIS BENNETT

126 An Eye for Music: Popular Music and the Audio-Visual Surreal, by John Richardson

CHRIS GAIR 128 Text and Drugs and Rock ' $n$ ' Roll: The Beats and Rock Culture, by Simon Warner 
MARTIN CLOONAN

RICHARD OSBORNE

ANNA M.J.M. PAISLEY

ADAM BEHR

KENNY FORBES EVA

MOREDA-RODRIGUEZ

LIZ GIUFFRE

MELISSA AVDEEFF

DAVID BLAKE

ALLAN MOORE

JUSTIN WILLIAMS BRIAN FAUTEUX

SIMON WARNER

JUN ZUBILLAGA-POW
130 Tell Tchaikovsky The News: Rock ' $n$ ' Roll, the Labor Question, and the Musicians' Union, 1942-1968, by Michael James Roberts

132 Reformatted: Code, Networks, and the Transformation of the Music Industry, by Andrew Leyshon

134 Soundscapes of Wellbeing in Popular Music, edited by Gavin J. Andrews, Paul Kingsbury and Robin Kearns

136 Reverberations: The Philosophy, Aesthetics and Politics of Noise, edited by Michael Goddard, Benjamin Halligan and Paul Hegarty; Resonances: Noise and Contemporary Music, edited by Michael Goddard, Benjamin Halligan and Nicola Spelman

139 Dance Floor Democracy, by Sherrie Tucker

141 How to Write About Music, edited by Marc Woodworth and Ally-Jane Grossan

143 Adapting Idols: Authenticity, Identity and Performance in the Global Television Format, edited by Koos Zwaan and Joost de Bruin

144 The Ringtone Dialectic: Economy and Cultural Form, by Sumanth Gopinath

146 Sweet Air: Modernism, Regionalism, and American Popular Song, by Edward P. Comentale

149 The Musicology of Record Production, by Simon Zagorski-Thomas

150 Sounding Race in Rap Songs, by Loren Kajikawa

153 Top 40 Democracy: The Rival Mainstreams of American Music, by Eric Weisbard

155 Litpop: Writing and Popular Music, edited by Rachel Carroll and Adam Hansen

157 Playing It Queer: Popular Music, Identity and Queer World-making, by Jodie Taylor 


\section{The Contributors}

IAN CAWOOD is reader in modern history and head of history at Newman University in Birmingham. He is the author of The Liberal Unionist Party: A History (I.B.Tauris, 2012) and editor of Joseph Chamberlain: International Statesman, National Leader and Local Icon (Palgrave Macmillan, 2016). He is a Senior Fellow of the Higher Education Academy.

Patryk Galuszka holds a PhD in management from the University of Lodz, Poland, and an LLM in law and economics from the Erasmus University Rotterdam, the Netherlands. Currently, he is an assistant professor in the Faculty of Economics and Sociology at the University of Lodz. His articles were published in journals such as First Monday, the International Journal of Communication, Popular Music and Society and the Journal of Internet Commerce. His research interests include the creative industries, popular music studies and media economics.

AMY KINTNER finished her PhD in musicology, specialising in popular music studies, in May of 2013. Since that time, she has taught various courses for the University of Rochester and worked as a professional freelance editor. Presently, she is the assistant editor for the Aspen Music Festival \& School in Aspen, Colorado. This is her first paper.

Charles Mueller received his PhD in historical musicology from Florida State University, and a Master's degree in music teaching from Portland State University. He is currently serving as an assistant professor of music history at Western Oregon University. Charles Mueller wrote his dissertation on the music of England's goth subculture, and his writings on popular music have been published in Volume: La revue des musiques populaires, Symposium: The Journal of the College Music Society and Gothic Studies.

AKSEL TJORA is professor of sociology at the Norwegian University of Science and Technology. His research interests include material-social interaction and communal processes in relation to organisation, culture, public and semi-public spaces, the Internet and personal technologies, as well as health and medicine.

Adam Trainer obtained his PhD from Murdoch University in 2006. He has taught film studies, cultural studies and popular music studies at Murdoch University, Curtin University and Edith Cowan University. He has published in film studies and popular music studies, and has undertaken research into the history of popular music and new music in Western Australia for both Curtin University and the State Library of Western Australia.

KATARZYNA M. WYrzYKOWSKA is a PhD candidate at the Institute of Philosophy and Sociology of the Polish Academy of Sciences and a lecturer in sociology at the Cardinal Stefan Wyszynski University in Warsaw. Her scientific interests include the sociology of music, the sociology of organisation and qualitative and interpretative research methodology. She is currently working on a research project entitled 'Dynamics of musicians' careers throughout the whole musical community in Poland' (with a Ministry of Culture and National Heritage research grant). 